\title{
A New Member of the Clover Proliferation Phytoplasma Group (16SrVI) Associated with EIm Yellows in Illinois
}

\author{
K. A. Jacobs, The Morton Arboretum, Lisle, IL 60532-1293; I.-M. Lee, Molecular Plant Pathology Laboratory, \\ USDA-ARS, Beltsville, MD 20705; H. M. Griffiths, Department of Plant Breeding, Cornell University, Ithaca, NY \\ 14853; F. D. Miller, Jr., Joliet Junior College, Joliet, IL 60431-8938; K. D. Bottner, Molecular Plant Pathology \\ Laboratory, USDA-ARS, Beltsville, MD 20705
}

\begin{abstract}
Jacobs, K. A., Lee, I.-M., Griffiths, H. M., Miller, F. D., Jr., and Bottner, K. D. 2003. A new member of the clover proliferation phytoplasma group (16SrVI) associated with elm yellows in Illinois. Plant Dis. 87:241-246.

A disease with symptoms similar to elm yellows (EY) was noticed in the early 1990s in suburban Chicago, IL. More than 1,000 mature American elms (Ulmus americana) have since died. Infected trees varied in the incidence and severity of canopy yellowing, leaf epinasty, butterscotch discoloration, and wintergreen odor of the phloem, but all developed a sparse and clumpy crown, uniformly necrotic phloem, and died within 2 years of showing canopy symptoms. Because symptoms were expressed irregularly and phytoplasma detection results by a commercial diagnostic company were inconsistent, a study was initiated to determine if EY phytoplasma was the causal agent. Polymerase chain reaction-restriction fragment length polymorphism (PCR-RFLP) methods using universal or EY phytoplasma specific primers were employed to detect putative phytoplasma(s) associated with 10 trees of varied disease severity within the outbreak region and 10 asymptomatic trees from an uninfected area (controls). Nested PCR using universal primers revealed that $90 \%$ of trees from the outbreak region were positive for phytoplasma while asymptomatic elms from another location (controls) tested negative. Phytoplasma-positive trees ranged in disease severity from 1 (asymptomatic) to 5 (near death). Inner bark samples chiseled from the lower trunk had higher phytoplasma detection rates than foliage or drill shavings. RFLP analyses and DNA sequencing of $16 \mathrm{~S}$ rDNA indicated that the phytoplasma recovered from dying elms in Arlington Heights is not related to the reference EY phytoplasma (group16SrV). It is most closely related to clover proliferation (CP) phytoplasma (group 16SrVI), and we have designated it Illinois Elm Yellows (ILEY) phytoplasma, and assigned it to a new taxonomic subgroup (16SrVI-C). EY phytoplasma was not detected in any samples, but two ILEY phytoplasma positive trees also were positive for aster yellows (AY) phytoplasma. ILEY phytoplasma was not detected in local leafhopper populations trapped in elm trees between May and September 2000. This is the first report of a phytoplasma related to $\mathrm{CP}$ phytoplasma causing elm yellows disease symptoms.
\end{abstract}

Additional keywords: leafhopper vectors, phloem necrosis, shade tree disease

More than 1,000 mature American elms have died during the last 10 years in a suburb west of Chicago, IL. The outbreak was first noted in 1991 when 10 trees died in the village of Arlington Heights, a community with nearly 10,000 mature parkway elms. The cause of death was unknown to the village forester, but symptoms differed from those of Dutch elm disease (DED) (13). By 1998, annual losses due to the malady totaled more than 150 trees, roughly equivalent to annual DED losses

Corresponding author: Karel Jacobs

E-mail: kjacobs@mortonarb.org

* The $\boldsymbol{e}$-Xtra logo stands for "electronic extra" and indicates that Figure 1 appears in color in the online edition.

Accepted for publication 26 September 2002.

Publication no. D-2002-1216-02R

(C) 2003 The American Phytopathological Society in the community. The mortality rate has yet to decline but appears to have leveled off. Still, during the past 2 years scattered elms have succumbed to the disease in other suburbs.

Elm yellows (EY), caused by a leafhopper-transmitted phytoplasma, was suspected in 1997 when the area was surveyed by the first author, but three peculiarities precluded a firm diagnosis: (i) inner bark samples taken in September 1997 and again in March 1998 from six symptomatic trees tested negative for phytoplasma (two eventually tested positive) according to a commercial diagnostics company (Agdia, Elkhart, IN); (ii) EY has historically been absent, save a few isolated reports, from the northern third of Illinois $(3,8,23)$, presumably because winter temperatures limit the reported vector, Scaphoideus luteolus Van Duzee; and (iii) one or more symptoms considered diagnostic of EY, i.e., premature yellowing and epinasty of foliage throughout the canopy and butterscotch discoloration of inner bark with an accompanying odor of wintergreen oil, were absent in some trees that later died. Our objectives were to determine if the causal agent of the disease was the EY phytoplasma and to assay elm-feeding leafhoppers for infectivity. Our results, based on restriction fragment length polymorphism (RFLP) analysis of polymerase chain reaction (PCR)-amplified 16S rDNA sequences, demonstrate a consistent association between dying elms and a new phytoplasma, Illinois Elm Yellows (ILEY) phytoplasma, suggesting it is the etiological agent of the disease in this region.

\section{MATERIALS AND METHODS}

Samples were taken between 1998 and 2002 from 10 mature parkway elms growing amidst the outbreak in Arlington Heights. The trees ranged in girth from 61 to $112 \mathrm{~cm}$ diameter at breast height and were at least several meters high. Ten asymptomatic trees located approximately 40 $\mathrm{km}$ south of the outbreak at The Morton Arboretum in Lisle, IL, where no evidence of EY disease is present, were sampled during fall 2001 to serve as controls. Fifty additional elms in the outbreak region have been under investigation (some also sampled) in a related, and still ongoing, study to evaluate treatment options. The disease in Arlington Heights is typically manifest as sparse foliage and clumping of terminal branches and foliage (Fig. 1). Canopy appearance was therefore utilized in assigning disease severity ratings (DSR) between 1 and 5 , where $1=$ healthy or asymptomatic canopy; $2=$ up to $25 \%$ of the canopy showing sparse, clumped foliage that was sometimes, but not always, yellow; $3=25$ to $50 \%$ of the canopy showing symptoms as described; $4=50$ to $90 \%$ of canopy as

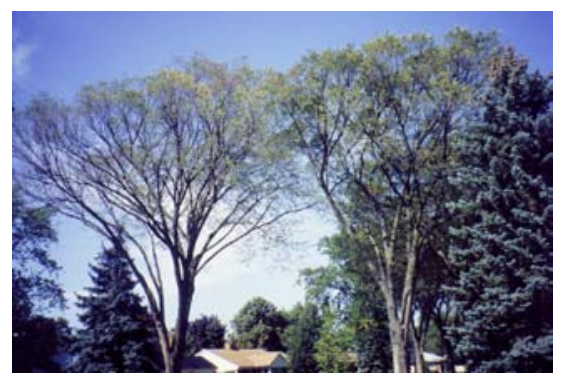

Fig. 1. Two American elms showing moderate symptoms of sparse, clumped, yellow foliage. 
described; $5=>90 \%$ of canopy devoid of leaves and tree at or near death. Ratings were assigned independently by two individuals, and the averages are reported (Table 1).

Three types of samples were taken when possible in an effort to find a less invasive, yet reliable, sampling method. Inner bark (mainly phloem) samples were collected by cutting a square, approximately $7 \times 7 \times$ $3 \mathrm{~cm}$ deep, from the trunk of each tree with a surface-disinfested chisel. Foliage samples were collected from low-hanging branches and drill shavings taken from the inner bark/cambium using a batteryoperated drill held $1 \mathrm{~m}$ off the ground. Inner bark samples were collected from the 10 control trees (DSR $=1)$. All samples were kept on ice and mailed overnight to I.-M. Lee, USDA-ARS, Beltsville, MD, for processing, or in the case of two samples, to H. M. Griffiths, Cornell University, Ithaca, NY. Inner bark samples sent to the commercial testing service were similarly prepared.

A standard procedure using existing universal primers designed to detect unknown phytoplasmas by PCR assays $(18,21)$ was used to process samples for phytoplasma detection. Total nucleic acid was extracted from ground leaf tissue with phenolchloroform as described by Lee et al. (16). To obtain the nucleic acid from inner bark samples, phloem was scraped off the bark pieces and ground in liquid nitrogen, and DNA was extracted with a DNeasy Plant Mini Kit (Qiagen, Valencia, CA) procedure as described by Green et al. (10). The
FastPrep instrument (Bio101, Inc., Vista, CA) was used to extract DNA from drill shavings according to manufacturer's instructions. A nested PCR was performed on all elm samples (including healthy controls) and negative control samples devoid of DNA template, using the universal primer pair $\mathrm{P} 1 / \mathrm{P} 7$ in the first reaction followed by amplification with a second set of primers, R16F2n/R16R2 (18,21). PCR was performed as described previously (17) in mixtures containing $1 \mu \mathrm{l}$ of purified undiluted nucleic acid for inner bark and shaving samples, diluted nucleic acid (1:30 in sterile water) for leaf samples or $1 \mu \mathrm{l}$ sterile water for negative controls, $200 \mu \mathrm{M}$ of each dNTP, and $0.4 \mu \mathrm{M}$ of each primer Nucleic acid extracted from leaf tissue was diluted to prevent inhibition of the PCR (I.M. Lee, unpublished). Diluted (1:30) PCR product $(1 \mu \mathrm{l})$ from the first amplification was used as template in the second-round PCR for all samples and controls. For PCR amplification, 35 to 38 cycles were con-

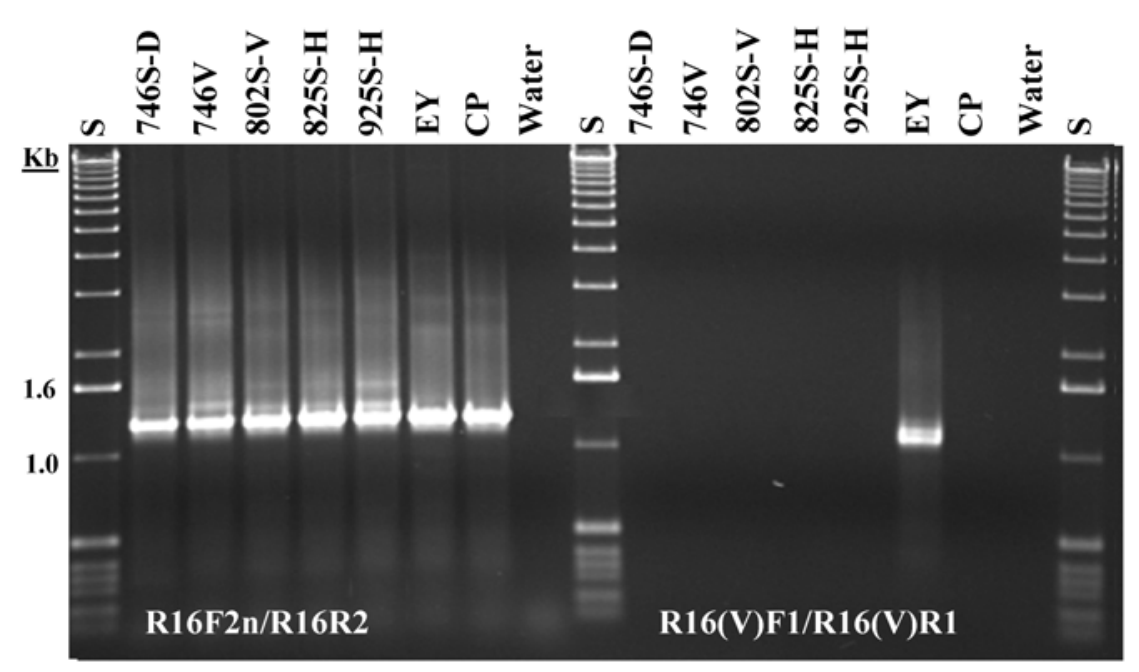

Fig. 2. Phytoplasma 16S rDNA from five trees (746S-D, 746V, 802S-H, 825S-H, 925S-H) and elm yellows (EY) and clover proliferation (CP) reference phytoplasma strains using universal primer pair P1/P7 followed by either R16F2n/R16R2 (left) or EY phytoplasma-specific primer pair R16(V)F1/R16(V)R1 (right). Note the absence of EY phytoplasma in trees that were positive for Illinois elm yellows (ILEY) phytoplasma. Nested polymerase chain reaction (PCR) products were separated by electrophoresis through a $1 \%$ agarose gel. Lane S, 1-kb DNA ladder.

Table 1. Identification of phytoplasmas in American elm trees

\begin{tabular}{|c|c|c|c|c|c|}
\hline Tree & Sampling date & $\begin{array}{c}\text { Disease severity } \\
\text { rating }^{\mathrm{a}}\end{array}$ & Tissue & $\begin{array}{c}\text { Phytoplasma detection } \\
\text { (nested PCR) }\end{array}$ & $\begin{array}{l}\text { Phytoplasma } \\
\text { identification }^{\mathbf{b}}\end{array}$ \\
\hline 926S-E & May 1998 & 3 & Inner bark & Positive & ILEY $^{c}$ \\
\hline \multirow[t]{3}{*}{$913 \mathrm{~S}-\mathrm{H}$} & May 1999 & 1 & Inner bark & Positive & ILEY \\
\hline & May 2000 & & Leaves & Positive & $\mathrm{AY}^{\mathrm{d}}$ \\
\hline & May 2000 & & Shavings & Positive & $A Y^{d}$ \\
\hline \multirow[t]{3}{*}{$802 \mathrm{~S}-\mathrm{V}$} & Feb. 2000 & 1 & Inner bark & Positive & ILEY $^{c}$ \\
\hline & May 2000 & & Leaves & Negative & - \\
\hline & May 2000 & & Shavings & Positive & ILEY \\
\hline 925S-H & Feb. 2000 & 4 & Inner bark & Positive & ILEY \\
\hline \multirow{3}{*}{ 746S-D } & June 2000 & 1 & Inner bark & Positive & ILEY \\
\hline & June 2000 & & Leaves & Negative & - \\
\hline & June 2000 & & Shavings & Positive & $A Y^{d}$ \\
\hline \multirow[t]{3}{*}{$746 \mathrm{~S}-\mathrm{V}$} & June 2000 & 4 & Inner bark & Positive & ILEY \\
\hline & & & Leaves & Negative & - \\
\hline & & & Shavings & Negative & - \\
\hline \multirow[t]{3}{*}{$826 \mathrm{~S}-\mathrm{H}$} & June 2000 & 5 & Inner bark & Negative $e^{\mathrm{e}}$ & - \\
\hline & & & Leaves & Negative & - \\
\hline & & & Shavings & Negative & - \\
\hline \multirow[t]{3}{*}{$825 \mathrm{~S}-\mathrm{H}$} & June 2000 & 3.5 & Inner bark & Positive & ILEY $^{c}$ \\
\hline & & & Leaves & Positive & ILEY \\
\hline & & & Shavings & Positive & - \\
\hline $720 \mathrm{~S}-\mathrm{V}$ & May 2002 & 5 & Inner bark & Positive & ILEY \\
\hline $843 \mathrm{~S}-\mathrm{V}$ & May 2002 & 3.5 & Inner bark & Positive & ILEY \\
\hline
\end{tabular}

${ }^{\text {a }}$ Disease severity ratings were based on canopy symptoms. $1=$ no symptoms; $2=25 \%$ of the canopy with sparse, clumped foliage; $3=25$ to $50 \% ; 4=50$ to $90 \% ; 5=>90 \%$ of canopy sparse and defoliated and tree near death.

${ }^{\mathrm{b}}$ Results based on nested polymerase chain reaction (PCR), restriction fragment length polymorphism (RFLP) analyses, and partial 16S rDNA sequences, as described in the text, unless otherwise noted.

${ }^{\mathrm{c}}$ Partial 16S rDNA sequences deposited with GenBank.

d Aster yellows phytoplasma.

${ }^{\mathrm{e}}$ Scarcity of viable phloem in sample is probable reason for negative result. 
ducted with AmpliTaq or AmpliTaq Gold polymerase. The following conditions were used: denaturation at $94^{\circ} \mathrm{C}$ for $1 \mathrm{~min}(2$ min for AmpliTaq or 12 min for AmpliTaq Gold for the first cycle), annealing for 2 $\min$ at $55^{\circ} \mathrm{C}$, and primer extension for 3 $\min \left(10 \mathrm{~min}\right.$ for the final cycle) at $72^{\circ} \mathrm{C}$.

Comparative nested PCR assays were performed to determine whether EY phytoplasma was present, but went undetected due to low concentration in five samples that were positive for ILEY phytoplasma. A separate nested PCR was performed on each sample using the universal primer P1/P7 followed by either the universal primers R16F2n/R16R2 or EY phytoplasmaspecific primer R16(V)F1/R16(V)R1 (17). Positive control samples of reference EY (=EY1) or CP phytoplasma strains (18) were included.

RFLP analyses of the nested PCR products $(1.2 \mathrm{~kb})$ were done for seven ILEYpositive samples using up to 12 restriction enzymes: MseI, AluI, RsaI, HhaI, HaeIII, HpaII, TaqI, HinfI, Sau3AI, KpnI, ThaI, and $B f a \mathrm{I}$, according to manufacturers' instructions (GIBCO-BRL, Grand Island, NY; New England Biolabs, Beverly, MA). DNA fragments were separated by $5 \%$ polyacrylamide gel electrophoresis, stained in ethidium bromide, and their profiles viewed under UV light. RFLP patterns from five trees are shown.

The P1/P7-PCR amplified products (1.8 $\mathrm{kb}$ ), extending from the $5^{\prime}$ region of the $16 \mathrm{~S}$ rDNA to the $5^{\prime}$ region of the $23 \mathrm{~S}$ rDNA, were purified from three Arlington Heights trees (926S-E, 746S-V, and 825SH) using Qiaquick PCR Purification Kit (Qiagen) and cloned into Escherichia coli using the TOPO-TA Cloning Kit (Invitrogen, Carlsbad, CA) according to manufacturers' instructions. The purified DNA fragments were sequenced (one clone per tree) using primers SP6, T7, and internal primers P5 (5'-CGGCAATGGAGGAA-
ACT- $3^{\prime}$ ) and F4 (5'-TGGTAGTCCACGCCGTAA-3') for $16 \mathrm{~S}$ rDNA. Partial $16 \mathrm{~S}$ rDNA sequences about $1.5 \mathrm{~kb}$ long were compared with GenBank and EMBL databases using the BLAST and DNASTAR programs (24).

During the summer of 2000, prior to identifying the ILEY phytoplasma, we attempted to determine if the reported vector of EY, S. luteolus (1), was present in the vicinity of the outbreak and other northeastern Illinois locations. A yellow sticky card (Great Lakes I.P.M., Vestaburg, MI) was placed daily in the canopies of eight mature elm trees in each of four locations: Arlington Heights, the neighboring community of Mount Prospect, the northern suburb of Lake Forest, and the Morton Arboretum in the western suburb of Lisle. Cards were collected each day except on weekends, wrapped in plastic wrap, and stored in a $-20^{\circ} \mathrm{C}$ freezer until further processing. Each card was examined mi-
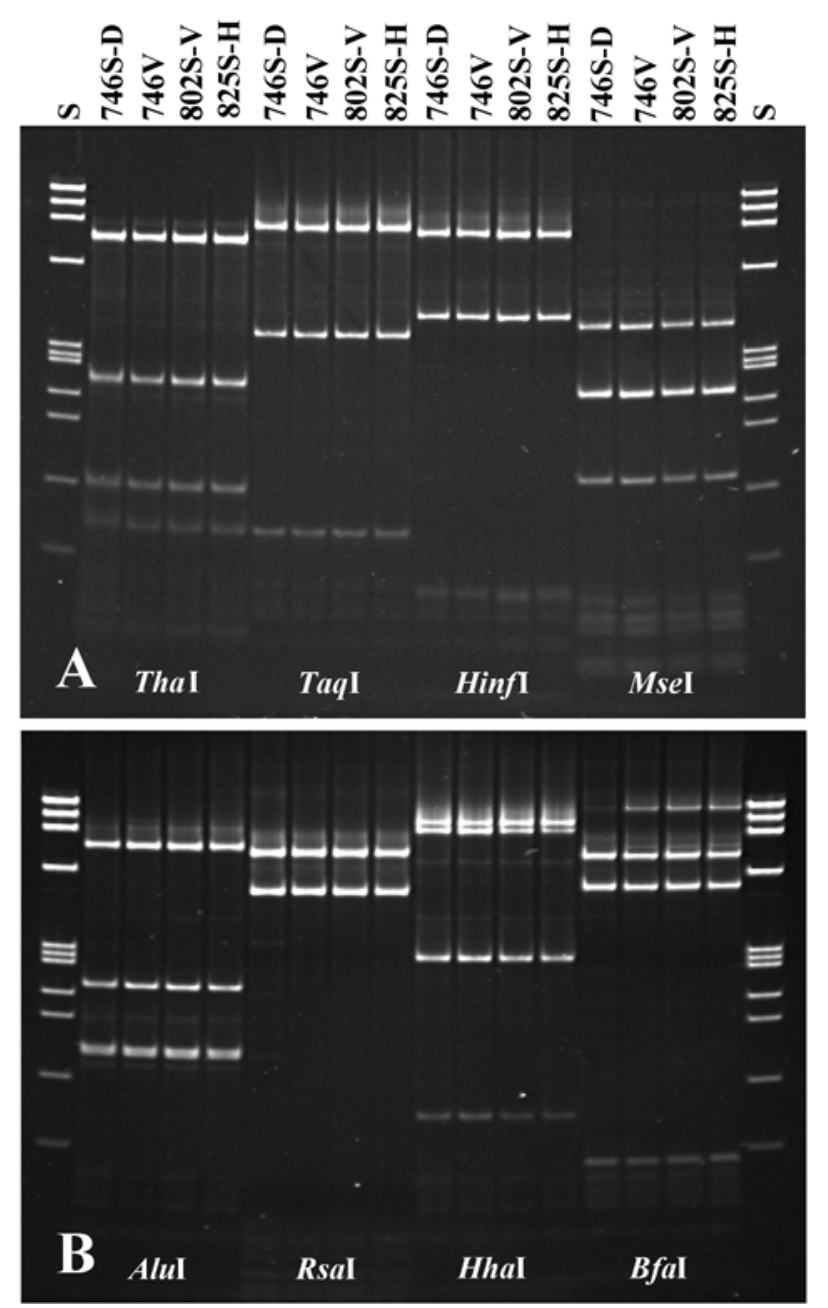

Fig. 3. Restriction fragment length polymorphism patterns of Illinois elm yellows (ILEY) phytoplasmas from four representative trees. 16S rDNAs were amplified with nested polymerase chain reaction (PCR) primer pair P1/P7 followed by R16F2n/R16R2, and products were singly digested with restriction enzymes: A, ThaI, TaqI, HinfI, or MseI, and B, AluI, RsaI, HhaI, or $B f a \mathrm{I}$, and separated by electrophoresis through a $5 \%$ polyacrylamide gel. Lane S, $\phi \mathrm{X} 174$ RFI DNA HaeIII digest, fragment sizes (bp) from top to bottom: 1,353, 1,078, 872, 603, 310, 281, 271, 234, 194, 118, 72. Lane 1, tree 746S-D; lane 2, tree 746V; lane3, tree $802 \mathrm{~S}-\mathrm{V}$; lane 4, tree $825 \mathrm{~S}-\mathrm{H}$.
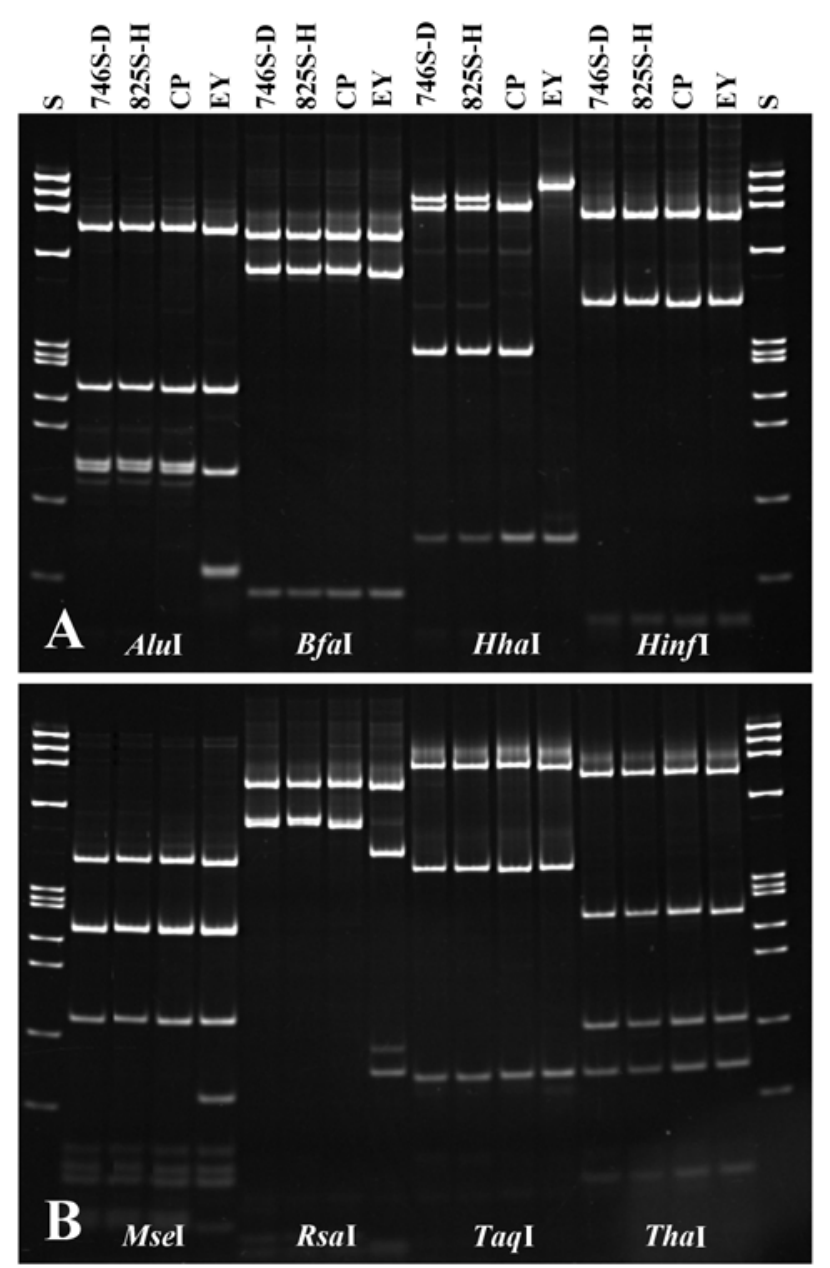

Fig. 4. Comparative restriction fragment length polymorphism patterns of Illinois elm yellows (ILEY) phytoplasma from two trees (746S-D and $825 \mathrm{~S}-\mathrm{H})$ and reference phytoplasma strains of clover proliferation (CP) and elm yellows (EY). 16S rDNA products amplified by nested polymerase chain reaction (PCR) using primer pair P1/P7 followed by R16F2n/R16R2 were singly digested with restriction enzymes A, AluI, $B f a \mathrm{I}, H h a \mathrm{I}$, and HinfI, and B, MseI, RsaI, TaqI, and ThaI. Fragments were separated by electrophoresis through a $5 \%$ polyacrylamide gel. Lane S, $\phi$ X 174 RFI DNA HaeIII digest, fragment sizes (bp) from top to bottom: 1,353, 1,078, 872, 603, 310, 281, 271, 234, 194, 118, 72 . 
croscopically for leafhoppers and related insects that are potential vectors of phytoplasmas. The leafhoppers were separated into 17 groups based on morphology, and individuals were scraped carefully with a surgical scalpel into a glass vial containing $95 \%$ ethanol and refrigerated. Vials were sealed and mailed overnight to the second author and refrigerated at $4^{\circ} \mathrm{C}$ until further processing. Total nucleic acid was extracted from 75 leafhoppers representing each morphological type by grinding the insect for 20 $\mathrm{s}$ at speed 4.5 in a Savant Fast Prep Machine (Q-BIOgene, Carlsbad, CA) in 0.5 $\mathrm{ml}$ CTAB extraction buffer (9) in a 2-ml microfuge tube. The extract was transferred to a clean 2-ml microfuge tube and processed using the method described above, in which a nested PCR using the primer pair $\mathrm{P} 1 / \mathrm{P} 7$ was followed by $\mathrm{R} 16 \mathrm{~F} 2 \mathrm{n} / \mathrm{R} 16 \mathrm{R} 2$. No positive controls were included in the insect assays.

\section{RESULTS}

Phytoplasma was detected with nested PCR in all but one of the 10 Arlington Heights trees (Table 1). All trees sampled before 2002 died within 2 years of exhibiting symptoms of a sparse, clumped canopy (Fig. 1). None of the 10 asymptomatic control trees from the Morton Arboretum tested positive for phytoplasma based on nested PCR.

Comparative nested PCR assays using universal primer pair $\mathrm{R} 16 \mathrm{~F} 2 \mathrm{n} / \mathrm{R} 16 \mathrm{R} 2$ in the second reaction yielded product for DNA from ILEY-infected elms and reference EY and CP phytoplasma strains (Fig. 2). In contrast, only the reference EY phytoplasma strain, traditionally associated with elm yellows disease, was amplified when the EY phytoplasma specific primer pair R16(V)F1/R16(V)R1 was used in the second reaction (Fig. 2).

The collective 16S rDNA RFLP patterns from the nine phytoplasma-positive trees listed in Table 1 indicate that the ILEY phytoplasmas are identical to one another (representative RFLP patterns shown in Fig. 3) but differ from the reference EY and CP phytoplasmas (Fig. 4). ILEY phytoplasma can be differentiated from EY phytoplasma by four restriction enzymes, AluI, HhaI, MseI, and RsaI, and from CP phytoplasma by one enzyme, HhaI. Restriction site analyses are consistent with the restriction site map derived from the 16S rDNA sequence data (Fig. 5).

The BLAST comparison of ILEY phytoplasma $16 \mathrm{~S}$ rDNA sequence data from three samples (GenBank accession num- bers: AF268895, AF409069, AF409070) indicated that ILEY has about $99 \%$ homology to $\mathrm{CP}$ phytoplasma and $98.5 \%$ homology to strawberry multicipita phytoplasma (subgroup 16SrVI-B) (12). Sequence data also indicated that the ILEY phytoplasma contains two heterogeneous operons, with one operon lacking an HhaI site between base pairs 200 and 300 . Based on these differences and other criteria proposed by Lee et al. (18), ILEY phytoplasma has been designated as a new subgroup (16SrVI-C) in the CP phytoplasma group.

Trees with a DSR ranging from 1 to 5 were positive for ILEY phytoplasma (Table 1). Although the sample size was small $(n=6), 86 \%$ of foliage and drill shaving samples were negative for phytoplasma compared to $10 \%(\mathrm{n}=10)$ of inner bark samples. All trees sampled prior to 2002 have died from the disease.

Between 11 June and 31 August 2000, a total of 959 leafhoppers and related insects were trapped. S. luteolus was not present among the insects trapped. Of the 75 leafhoppers assayed individually, none were positive for ILEY, EY, or CP phytoplasmas. One leafhopper (Scaphytopius sp.) tested positive for aster yellows (AY) phytoplasma.

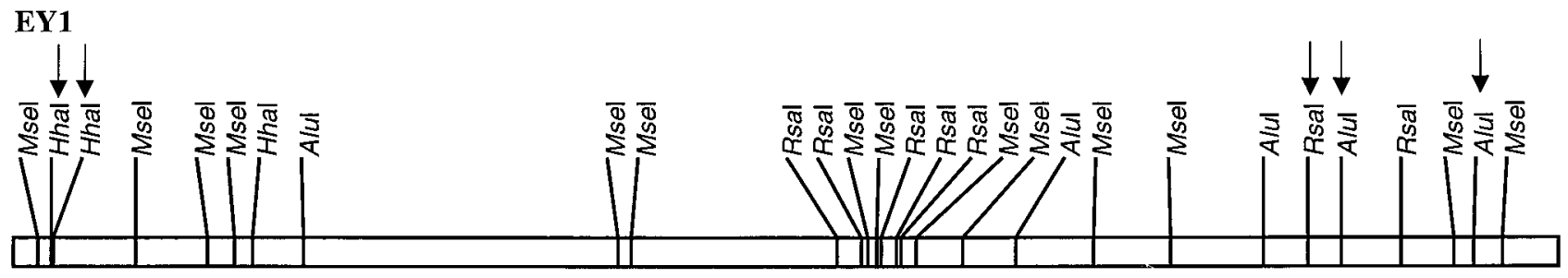

\section{IL-EY}

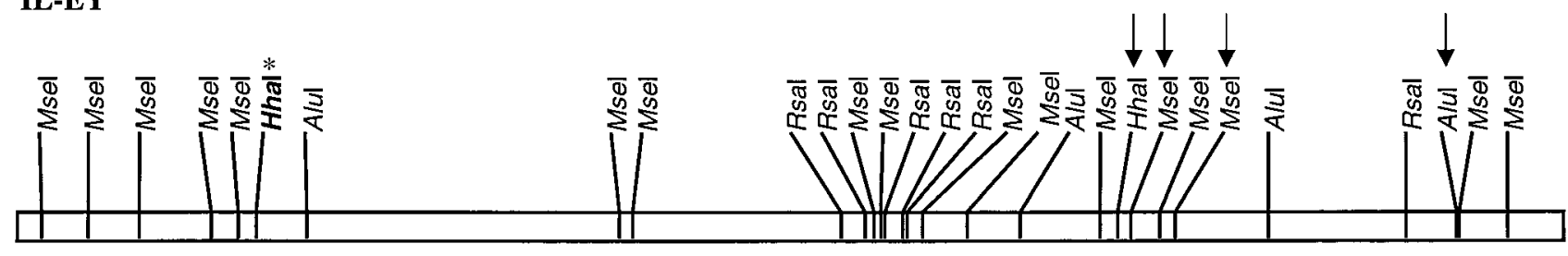

CP
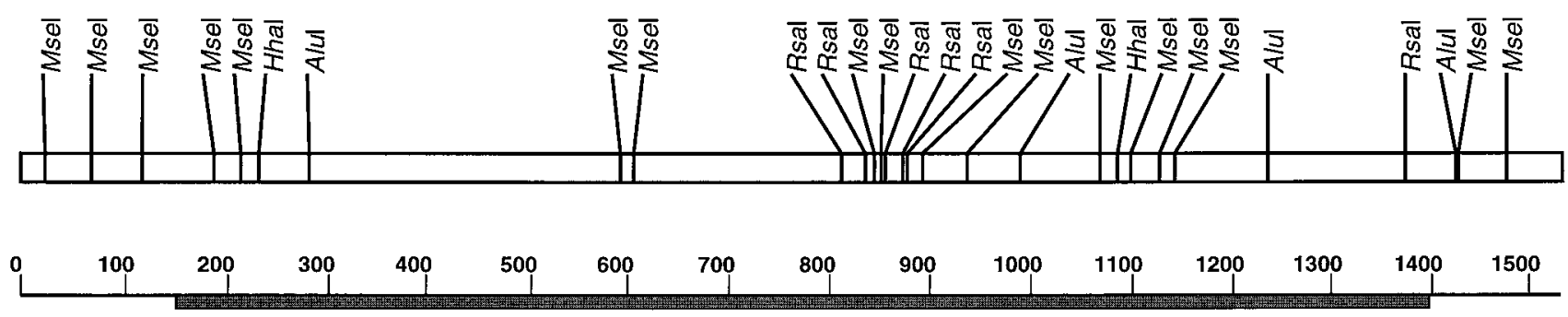

Fig. 5. Maps of putative restriction sites in the nucleotide sequence of 16S rDNA from elm yellows (EY), Illinois elm yellows (ILEY), and clover proliferation (CP) phytoplasmas. The solid bar on the scale represents the region amplified by nested primer pair R16F2n/R16R2. Arrows indicate sites that differ between ILEY and EY phytoplasmas. The ILEY phytoplasma has two heterogeneous 16S rDNA operons with one operon lacking a HhaI site between base pairs 200 and 300 . 


\section{DISCUSSION}

The presence of ILEY phytoplasma is well correlated with the development of an EY-like syndrome in Arlington Heights American elms. The appearance of the disease is similar to that reported historically as elm yellows or elm phloem necrosis. However, certain symptoms reported to be diagnostic for $\mathrm{EY}$, namely, uniform yellowing of the canopy and epinasty of leaves in midsummer, an aroma of wintergreen oil and butterscotch discoloration of the phloem $(2,3,13,22)$ were expressed with variable incidence and severity in the Arlington Heights elms. ILEY phytoplasma was detected in trees with and without phloem discoloration and the wintergreen aroma, as well as in trees exhibiting no canopy symptoms (DSR $=1$ ). Nonetheless, the appearance of a sparse canopy with clumps of foliage was, in our experience, the most reliable symptom of the disease and could be useful for early diagnosis.

Reliance upon DNA detection methods to diagnose ILEY was problematic because of the difficulty in collecting ample quantities of phloem and the apparent risk of obtaining false negatives. Foliage and drill shavings were less intrusive methods of collecting samples, but the tissues appeared to yield higher false negatives $(86 \%)$ than inner bark (10\%). However, low replication and differences in DNA extraction and amplification methods among sample types precluded an adequate comparison of detection frequency data. Seasonal and spatial variation in phytoplasma distribution and titer is known to exist in trees and other perennial hosts (17). An improved understanding of this variation and variation associated with different tissues in elm would assist in phytoplasma detection efforts.

Until now, EY disease in North America has been thought to be caused only by strains of the EY phytoplasma $(11,16,23)$. In Europe, EY is always associated with an EY phytoplasma, but mixed infections frequently occur, sometimes with AY phytoplasma (14). AY phytoplasma was present in low titer in two elms in our study, but in both cases the predominant phytoplasma DNA amplified was that of ILEY. The importance of mixed infections in this disease is unknown, but they occur commonly in other phytoplasma diseases (17). Typically, although not always, the predominant phytoplasma is the primary pathogen. Still, low titer strains may influence disease expression, especially in perennial hosts (17).

The RFLP and DNA sequencing data indicate that ILEY phytoplasma is most closely related, but not identical, to $\mathrm{CP}$ phytoplasma, a member of the taxonomic group $16 \mathrm{SrVI}(5,15,18)$. The $\mathrm{CP}$ phytoplasma is considered a pathogen of herbaceous plants, but it has a poorly defined host range. The host range is presumed to be similar to that of the beet leafhopper transmitted virescence agent (BLTVR). BLTVR is another phytoplasma in taxonomic group $16 \mathrm{SrVI}$ and it infects a variety of vegetable species, herbaceous ornamentals, and weed species (9).

The vectors of $\mathrm{CP}$ are, principally, the aster leafhopper Macrosteles quadrilineatus Forbes $(4,20)$, and the beet leafhopper (Circulifer tenellus (Baker)), which are widely distributed in the United States. Both leafhoppers have migrating and sometimes overwintering populations in the Midwest. Neither was found among the 100 Cicadellidae and Fulgoridae collected on elm by Gibson (7). We did not identify to species most of the insects collected on sticky cards, but none of those assayed were carriers of ILEY, CP, or EY phytoplasmas. We neglected to include a positive control in the insect assays, which increases the likelihood that we obtained false negatives; however, as AY phytoplasma was detected in one leafhopper, the PCR assays were at least capable of detecting phytoplasma in the insects.

Discovering that the phytoplasma in dying elms is related to CP phytoplasma suggests that vectors of the CP phytoplasma may also be vectors of ILEY. During the 1980s, overwintering populations of the aster leafhopper were present in Wisconsin (19). Similarly, beet leafhoppers migrated to the upper Midwest during this time and caused severe outbreaks of horseradish brittle root disease (caused by Spiroplasma citri) in Illinois and Wisconsin (6). Although speculative, it is possible that the presence of these leafhoppers in large numbers in the upper Midwest during the 1980s resulted in transient feeding on elm and the current outbreak of ILEY. Studies continue to assess the infectivity of local leafhopper populations and the efficacy of using systemic insecticides to deter potential vectors from feeding and spreading this lethal disease.

\section{ACKNOWLEDGMENTS}

We appreciate the assistance of Arlington Heights forester Owen Widmayer and his staff, and the insect collections made by Mount Prospect and Lake Forest village foresters. We are grateful for insight offered by W. A. Sinclair and useful comments on the manuscript by two anonymous reviewers and Jacqueline Fletcher, Thomas Harrington, Nigel Harrison, and Dayle Saar. Field and sampling assistance was provided by R. Bastian, K. Ludwig, L. Berg, and D. Thorpe. This research was partially funded by the Illinois Arborist Association and Illinois Landscape Contractor Association.

\section{LITERATURE CITED}

1. Baker, W. I. 1949. Note on the transmission of the virus causing phloem necrosis of American elm, with notes on the biology of its insect vector. J. Econ. Entomol. 42:729-732.

2. Braun, E. J., and Sinclair, W. A. 1979. Phloem necrosis of elms: Symptoms and histopathological observations in tolerant hosts. Phytopathology 69:354-358.

3. Carter, J. C. 1961. Illinois Trees: Their Diseases. Illinois Natural History Survey Circ. 46. Illinois Natural History Survey, Urbana.
4. Chiykowski, L. N. 1964. Current Canadian research on leafhoppers in relation to virus diseases. Phytoprotection 45:108-116.

5. Deng, S., and Hiruki, C. 1991. Genetic relatedness between two nonculturable mycoplasmalike organisms revealed by nucleic acid hybridization and polymerase chain reaction. Phytopathology 81:1475-1479.

6. Fletcher, J. 1985. Brittle root of horseradish in Illinois and the distribution of Spiroplasma citri in the United States. Phytopathology 73:354-357.

7. Gibson, L. P. 1973. An Annotated List of the Cicadellidae and Fulgoridae of Elm. U.S. Dep. Agric. For. Serv. Res. Pap. NE-278.

8. Gibson, L. P. 1977. Distribution of elm phloem necrosis in the United States. Plant Dis. Rep. 61:402-403.

9. Golino, D. A., Oldfield, G. N., and Gumpf, D. J. 1989. Experimental hosts of the beet leafhopper-transmitted virescence agent. Plant Dis. 73:850-854.

10. Green, M. J., Thompson, D. A., and MacKenzie, D. J. 1999. Easy and efficient DNA extraction from woody plants for the detection of phytoplasmas by polymerase chain reaction. Plant Dis. 83:482-485.

11. Griffiths, H. M., Sinclair, W. A., BoudonPadieu, E., Daire, X., Lee, I.-M., Sfalanga, A., and Bertaccini, A. 1999. Phytoplasmas associated with elm yellows: Molecular variability and differentiation from related organisms. Plant Dis. 83:1101-1104.

12. Jomantiene, R., Davis, R. E., Dally, E. L., and Maas, J. L. 1998. The distinctive morphology of Fragaria multicipita is due to phytoplasma. HortScience 33:1069-1072.

13. Lanier, G. N., Schubert, D. C., and Manion, P. D. 1988. Dutch elm disease and elm yellows in central New York: Out of the frying pan into the fire. Plant Dis. 72:189-194.

14. Lee, I.-M., Bertaccini, A., Vibio, M., Gundersen, D. E., Davis, R. E., Mittempbergher, L., Conti, M., and Gennari, F. 1995. Detection and characterization of phytoplasmas associated with disease in Ulmus and Rubus in northern and central Italy. Phytopathol. Mediterr. 34:174-183.

15. Lee, I.-M., Davis, R. E., and Hiruki, C. 1991. Genetic relatedness among clover proliferation mycoplasma-like organisms (MLOs) and other MLOs investigated by nucleic acid hybridization and restriction fragment length polymorphism analyses. Appl. Environ. Microbiol. 57:3565-3569.

16. Lee, I.-M., Davis, R. E., Sinclair, W. A., DeWitt, N. D., and Conti, M. 1993. Genetic relatedness of mycoplasma-like organisms detected in Ulmus spp. in USA and Italy by means of DNA probes and polymerase chain reactions. Phytopathology 83:829-833.

17. Lee, I.-M., Gundersen, D. E., Hammond, R. W., and Davis, R. E. 1994. Use of mycoplasma-like organism (MLO) groupspecific oligonucleotide primers for nestedPCR assays to detect mixed MLO infections in a single host plant. Phytopathology 84:559566.

18. Lee, I.-M., Gundersen-Rindal, D. E., Davis, R. E., and Bartoszyk, I. M. 1998. Revised classification scheme of the phytoplasma based on RFLP analyses of 16sRNA and ribosomal protein gene sequences. Int. J. Syst. Bacteriol. 48:1153-1169.

19. Mahr, S. E. R., Wyman, J. A., and Chapman, R. K. 1993. Variability in aster yellows infectivity of local populations of the aster leafhopper (Homoptera: Cicadellidae) in Wisconsin. J. Econ. Entomol. 86:1522-1526.

20. Nielson, M. W. 1979. Taxonomic relationships of leafhopper vectors of plant pathogens. Pages 3-27 in: Leafhopper Vectors and Plant Disease Agents. K. Maramorosch and K. 
Harris, eds. Academic Press, New York.

21. Schneider, B., Seemüller, E., Smart, C. D., and Kirkpatrick, B. C. 1995. Phylogenetic classification of plant pathogenic mycoplasma-like organisms or phytoplasmas. Pages 369-380 in: Molecular and Diagnostic Procedures in Mycoplasmology, Vol. 1. S.
Razin and J. G. Tully, eds. Academic Press, New York.

22. Sinclair, W. A. 1981. Elm Yellows. Pages 2531 in: Compendium of Elm Diseases. American Phytopathological Society, St. Paul, MN.

23. Sinclair, W. A. 2000. Elm Yellows in North America. Pages 121-136 in: The Elms: Breed- ing, Conservation, and Disease Management C. P. Dunn, ed. Kluwer Academic Publishers, Boston, MA.

24. Tatusova, T. A., and Madden, T. L. 1999. BLAST 2 sequences, a new tool for comparing protein and nucleotide sequences. FEMS Microbiol. Lett. 174:247-250. 